Society for the Anthropology of Work • Policing and Labor

\title{
Abolish, Defund, and the Prospects of Citizen Oversight after George Floyd
}

\section{Theresa Rocha Beardall}

Published on: Dec 01, 2020

Updated on: Nov 30, 2020

DOI: $10.21428 / 1 \mathrm{~d} 6$ be30e.5feeb270

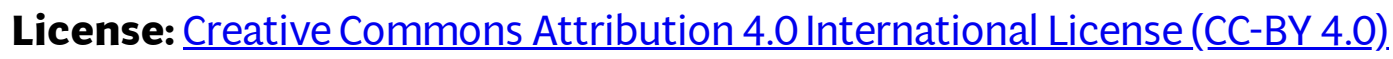


On May 25, 2020 in Minneapolis, Minnesota, George Floyd was taken into police custody after a store clerk reported the possible passing of a counterfeit $\$ 20$ bill and public intoxication. Within minutes, Floyd was handcuffed and pinned face-down by two officers while a third, Officer Derek Chauvin, kneeled on his neck. Despite persistent pleading by Floyd and several bystanders saying that "he's not breathing" and to "get the fuck off him," Chauvin refused to move and took Floyd's life. Protests erupted across the United States - and the world - for several weeks demanding that Floyd's murderers be held accountable. These collective actions ushered in an urgent call to defund and abolish the police and sparked unprecedented and widespread efforts to reimagine U.S. policing as we know it.

In this short piece, I address and contribute to such efforts by bringing attention to the possibilities that police labor and employment law broadly, and the role of citizen review boards (CRBs) more specifically, can afford to meaningfully address police violence. Drawing from two years of ethnographic research in Syracuse, New York, I argue that, despite existing critiques, the history and contemporary infrastructure of CRBs is crucial to the present moment because, in many cases, these agencies emerged from Black and Brown organizing to control local police. They originally had, and largely continue to have, demands that resonate with protests against the murder of George Floyd today (Rocha Beardall 2019).

\section{The Future of Policing is Police Employment}

Discussions of abolition, defund, and citizen review would do well to foreground the legal and procedural context of police employment. Police officers are taxpayer-funded public servants governed by employment contracts between cities, officers, and police unions. Collective bargaining agreements (CBAs) are common and define the terms and conditions of employment, compensation, benefits, and disciplinary measures particular to the policing profession. Civil service laws and city charters also govern policing and prevent municipalities and departments from unilaterally changing work rules, compensation, or formal discipline without first negotiating with police or petitioning lawmakers to change relevant law. This ironclad employment structure is integral to issues of police misconduct and should be prioritized by protest movements against it. The following sections elaborate on and consolidate key concepts in current protest movements with respect to primary elements of police employment. I see these connections as essential to the tangible transformation of American policing, particularly in the context of community efforts to influence and restructure municipal agreements that govern local police and police violence. 


\section{Abolish the Police}

As defined by the critical geographer Ruth Wilson Gilmore (2019), abolition is "about presence, not absence. It's about building life-affirming institutions." In Wilson's abolitionist perspective, addressing the origins of social insecurity is critical, because it allows society to be reimagined as a set of resourceabundant communities with opportunities for stable employment, living wages, vibrant education, and nutritious food - all of which decrease the risk of violence and dependence on police. As a result, abolition is a dual movement toward dismantling violent institutions, such as prisons, policing, and immigrant detention centers, and building the means through which communities can collectively thrive. In some communities, abolishing the police means reductions in policing that lead to their eventual elimination, while others want police departments to be dissolved immediately. Underscoring the necessity of abolition, protests throughout the summer of 2020 sounded the alarm that reformist efforts are unacceptable and insufficient to address police violence. That is, policies and programs such as body cameras and community policing that fail to address social insecurities and ultimately expand the role of police in society cannot be the way forward. Instead, police abolition requires a radical shift in the labor and employment mechanisms that govern policing and entrench police as a nonnegotiable component of modern social life.

\section{Defund the Police}

Defunding the police ultimately means narrowing the scope and scale of police responsibilities and redirecting law enforcement funds to other government services such as health care, housing, trauma centers, and mental health centers. This budgetary shift holds tremendous possibility for improving the quality of life for countless Americans, especially vulnerable populations. Defunding.proponents argue that highly trained community response teams with mental health clinicians should respond, without police presence, to community members in situations including a mental health crisis, distress, and homelessness. Police are routinely called to assist in these instances, but the presence of an officer with a gun may escalate such encounters. In fact, recent data indicate that one in every four persons killed by police were dealing with mental illness at the time of their death.

Demands to defund the police represent yet another case where engaging with police employment proves to be highly significant. While this is not generally understood by the general public, a redirecting of law enforcement funds to community response teams can actually be accomplished within a municipality's standard employment mechanisms. Municipal budgets are generally created by the mayor or city manager and approved by the city council. Once approved, the mayor or city manager administers the funds. These procedures signal that city officials can be lobbied by taxpayers to reduce the amount and function of local police funding. In many cases, these requests can be creatively accomplished without violating the relevant CBA or the state rules that govern police work. Some employment-related avenues that limit police spending and reflect current protest demands 
include reducing overtime, hiring fewer officers, implementing furlough options, and examining perks such as paid parking and the use of take-home vehicles (Rocha Beardall 2019). A serious review of overtime, an increasingly expensive and largely unbudgeted taxpayer expenditure, can be particularly impactful as such a review requires a thorough analysis of whether police employees are best suited to address pressing community concerns.

\section{Citizen Review Boards}

Prior movements to reduce the power, scope, and abusive tendencies of police created several tools and mechanisms to demand accountability for egregious police behavior. Citizen review boards, for example, are municipal oversight agencies staffed by city employees and a group of citizens appointed by the mayor and/or city council to receive, review, investigate, and/or make determinations regarding citizen complaints involving police. Board structures vary greatly from city to city, generally falling into three broad categories: a review model that examines the work products of internal affairs investigations, an investigative model that receives and independently investigates citizen complaints, and an auditor model that systematically monitors the receipt and review of citizen complaints for fairness (Finn 2001). CRB powers vary across these models, which range from citizen agencies that investigate police misconduct with and without subpoena power to agencies that advise departments on their policies and procedures with and without investigatory powers (Perino 2004). In addition to these formal responsibilities, CRBs are often expected to improve police training so as to reduce future misconduct, build trust and reassurance between the community and the police, and serve as the conduit of citizen concerns to the police chief, mayor, and city council.

CRB proponents argue that citizen oversight demands more evidence and greater transparency from police about their actions, takes a stricter view of police misconduct, and eventually improves the thoroughness and equity of internal police investigation units. Proponents also argue that effective citizen oversight may dissuade officers from engaging in misconduct for fear of the resulting disciplinary procedures, which could result in limited promotions, unfavorable work duties, and possible termination (Finn 2001). Critics, on the other hand, argue that CRBs are toothless agencies with little or no power to effect meaningful change. They also argue that CRBs tend to handle police violence and misconduct as exceptionally rare occurrences and, in the process, reify the everyday violence of policing as a legitimate system that merely needs minor reform. As a result, these efforts may provide the veneer of citizen oversight but, in actuality, do little to stand up against the structural violence of U.S. policing.

Despite these valid critiques of CRBs, my ethnographic fieldwork in Syracuse, New York suggests that these agencies have an overlooked and underdeveloped utility that can assist movements organizing to defund and abolish the police. In what follows, I address critiques of CRBs by offering my recommendations about where we might go from here. Specifically, I argue that the emergence of 
these agencies from a deep history of community resistance against police violence, as well as the dynamic and nationwide architecture of CRBs, offer the potential for greater control of local policing. Here, I focus on two major possibilities for CRBs, which move beyond an unproductive preoccupation with their shortcomings.

First, many CRBs are the result of decades-long fights by communities of color that hoped to take control over and effectively reduce the size and significance of police in their localities. In the city of Syracuse, citizens first advocated in 1979 for complete citizen control of the police. The municipality eventually responded in 1993 with a watered-down version of community demands that, among other key limitations, prevented residents from thoroughly investigating police misconduct or having a formal voice in disciplining and firing police (Rocha Beardall 2019). These deficiencies were intended to ensure oversight ineffectiveness. Today in Syracuse, and in hundreds of other cities across the United States, CRBs largely remain toothless, not because of a lack of community desire for change but because police unions aggressively fight any citizen initiative that increases police accountability. Another reason for the supposed ineffectiveness of CRBs is that instead of responding to citizen demands for increased protection against violent policing, city officials are repeatedly swayed by police union lobbying and calls for reforms that grow the size, budget, and reach of policing. Despite these obstacles, I argue that CRBs can fulfill their community-centered purpose with increased engagement and targeted improvements. In fact, changes that vest CRBs with their full and originally desired investigatory and subpoena powers could be accomplished quickly.

Second, CRBs are municipal infrastructures composed of city employees and community volunteers who have firsthand knowledge about the limits and possibilities of police employment as a mechanism for social change. There are upward of 144 CRBs in the United States and recent events suggest that this number is growing. I urge abolition and defund movements to leverage this infrastructure and expand CRBs' community education mandate to promote transparent union bargaining. Specifically, CRBs must champion the education of residents and city council members on the mechanics and details of a police contract before and while it is negotiated, approved, and implemented. In this way, CRB advocacy can move aspects of bargaining out of secrecy and into the public spotlight. CRBs must also demand public access to police disciplinary records, systematic reductions in the size of the police force, community-led participatory police budgeting, immediate caps on overtime pay, and expanded police disciplinary policies such as the duty to intervene when a fellow officer is threatening someone's life.

In addition to CRBs, abolition and defund movements should enter into conversation and collaboration with municipal governments more broadly. Well before the summer of 2020, Syracuse city councilors made aspects of the tentative CBA-based budget public by carefully reviewing the costs and announcing several major financial errors. Council eventually voted down the CBA in 2019, because the 
budget indicated that the mayor's office made too many police concessions with too few meaningful gains for city residents. As recently as July 2020, in response to community protest and organizing, Syracuse state legislators introduced a bill that would give the mayor's office more control over disciplining the police and take power away from the police union by amending New York's Civil Service Law. As these examples show, movements to reimagine policing can leverage the work of municipalities and push officials to expand these efforts further. I am hopeful that, when working collaboratively, we might arrive at a time when the community truly holds the power to hire and fire officers, fund department initiatives as they see fit, or abolish policing altogether.

\section{Author Bio}

Theresa Rocha Beardall, JD, PhD (Oneida/Sault Ste. Marie/Mexican) is Assistant Professor of Sociology, Criminology, and American Indian Studies at Virginia Polytechnic Institute and State University. Her scholarship examines how systems of law and agents of the state enact and enforce various modes of state violence. In one thread of this research, she bridges insights from race studies, labor law, social movements, and political sociology to reframe police as workers in the context of police unions, citizen review boards, and local community activism against police violence.

\section{Preview Image}

Photo by Chris Henry.

\section{References}

Finn, Peter. 2001. “Citizen Review of Police: Approaches and Implementation." Report. Washington, DC: National Institute of Justice.

Gilmore, Ruth Wilson. 2019. Keynote conversation, Making and Unmaking Mass Incarceration conference, University of Mississippi, Oxford, MS, December 5.

Perino, Justina R. Cintrón. 2004. “Developments in Citizen Oversight of Law Enforcement." Urban Lawyer 36(2): 387-98.

Rocha Beardall, Theresa. 2019. "Transactional Policing: Reframing Local Police-Community Relations Through the Lens of Police Employment." PhD dissertation, Cornell University. 